\title{
The government's perception of the conflict at the cement plant in Rembang
}

\author{
Suyahmo $^{1}$, Sidik Puryanto ${ }^{2}$, Dewi Liesnoor Setyowati ${ }^{3}$, Aries Nugraheni ${ }^{4}$ \\ \{suyahmo@gmail.com ${ }^{1}$, sidikpuryanto@gmail.com², liesnoor@yahoo.co.id ${ }^{3}$, \\ nugraheniaries@gmail.com ${ }^{4}$ \} \\ ${ }^{1}$ Universitas Negeri Semarang, Indonesia \\ ${ }^{2}$ Universitas PGRI Ronggolawe Tuban, Indonesia \\ ${ }^{3}$ Universitas Negeri Semarang, Indonesia \\ ${ }^{4}$ SMP 4 Kismantoro Wonogiri
}

\begin{abstract}
This study aims to analyze the government's perception of the conflict of cement factories in Rembang, Central Java. This study used a phenomenological approach, based on the analysis of Hegel, dan Budiman. The results of this study indicate that there are differences in views from the local government and the central government on the conflict in the cement plant in Rembang. the source of ideas found from the regional government shows the approach to the right of power and the authority of regional autonomy, while the central government places more on community humanization. The conclusion of this study shows that there is a policy imbalance made by the regional government with the central government. Policy inequality creates obstacles to the implementation of the cement plant in Rembang.
\end{abstract}

Keywords: perceptions, government, conflict, mining, imbalance policy

\section{Introduction}

The dualism of State functions in the context of development raises various views that actually question the ability of the State to implement these two functions. In the context of the field it is known that the State is still not able to maintain the balance of these two functions, but the State is more towards alignments. As mentioned by Budiman [1],[2], [3] in playing the role of development the government has objective and subjective functions. The objective function that must be carried out by the government is related to efforts to provide justice, welfare for every citizen. In other words, the objective function of the government is seen from the macro context, based on the principle of a large system, where it has become the duty and responsibility of a country with its government obliged to fulfill the life needs of every individual living in it, including social, economic, cultural, political needs. and law.

The goal of development rather than society of development government uses unilateral fairness, under the pretext of accelerating progress in order to realize justice and prosperity of the people. The result is inequality and social inequality between the rich and the poor, the poor are increasingly oppressed, justice and universal welfare are still far from expectations, as written in the history of the development concept in the New Order era, not justice and social welfare are seen from various contexts, but development is seen from the quantity of the economy, while the other qualities are neglected. 
People in the early era of modernization had a patron client relationship, as a macro society that must submit to the macro needs of the government system, by utilizing inlander culture, natives who are ngawulo dhawuh gusti and sendiko dawuh is a tool that has the power to force, military power applied as a means to force, and oppress those who oppose.

In the new order era, people were more likely to become macro actors than micro actors, who were more likely to obey the macro system of government as a means to realize their objective functions, in the realization of justice and social welfare. Because it is more likely to use a macro approach, what happens next is not as a mutually sustainable system, but a hegemony on the basis of legitimacy of power, and the strength of a large system, centralization and top down policies. The beginning of the reforms was called the beginning of the community of micro actors starting to be involved in every event carried out by the government, because the right to freedom of speech was wide open, democracy within the framework of the Unitary Republic of Indonesia developed towards the substance of democracy, (1) Recognition of Human Rights as an award for human dignity, (2) Recognition of people's participation in government [4].

Since after that, community groups belonging to (micro) minority groups have begun to dare to move, and show identity actualizing themselves with the interest of their rights that have been confined to the power of perenialism which the government has shown. Being open after the reform era for the government is an obligation as a function of protection, justice and welfare on a macro basis, in order to realize the progress of democracy to care more about minority groups. State functions in the post-reform era still tend to be under the shadow of the macro with what the previous government has done, more inclined to quantity than absolute quality, whereas deliberation as a basic way that is more directed towards the substance of democracy in every decision as if left alone is marginalized because lack of awareness from each of them. Awareness because of interests, and not on the basis of honesty is often shown by decision makers, which results in unilateral decisions, and tends to leave absolute quality.

Since the community has been actively involved in the present era there has been a positive impact in the dimension of democratic governance, where the public has sufficiently understood objective functions as part of democracy, which has the right to freedom of opinion, and the right to aspiration. In other words, the objective function of society is increasing, indicating that the level of civil society is increasing, and to accompany the present condition, of course, awareness of the government, capitalist tools, and other capitalist actors is needed to understand the history of development in society, the era of coercion, the era Macro quantity should have been abandoned, replaced by a new era in a more humanist development approach, and directed towards society in general, such as theoretical developments which form the basis of society as the subject of development (society as subject of development). The purpose of this study is to analyze the role of the government and the government's argument for the construction of a cement plant in Rembang.

\section{Method}

This study uses a phenomenological qualitative approach. The different phenomena from the local government and the central government to the case of the conflict in the cement plant in Rembang, must be depth understanding. The views and hidden reasons are the arguments and the basis for the opinion. The qualitative approach uses the interview method as the primary 
method and the reference method from various newspaper media as a secondary method. Data analysis uses three concepts, namely data reduction, data verification, and conclusions.

\section{Result and discussion}

\subsection{The Local government's role in the case of the cement plant in Rembang}

The role of the government in resolving conflicts is more in the context of how to become managers of conflict (governance). The role of the state must be able to become a safety falcon in uncovering conflicts that occur within the community and the corporation. Governance is governance that does not only cover the state and government, but also includes two other parties, namely the public and the private sector. The government in good governance has the largest role and central structure in the network between parties, while other parties provide policy input from the start of the planning process and the implementation process. In the three access relationship, if there is a conflict, the role of the government does not work with the function of the jury and the manager.

The government must be able to become an intermediary, which functions (1) stands in the middle of neutral, seeks both parties in conflict in order to reach the meeting point, agreement on synthesis, (2) strive for both parties not to lower their dignity and dignity ( 3 ) strive for both parties to feel profitable, as well as gain profits and no harm, (4) strive for both parties to realize that life is dynamic, full of challenges and do not leave togetherness and harmony as a buffer for social life [5]. The government must balance between economic, socio-cultural interests, between the community, the owners of capital and the interests of the government itself. It does not necessarily mean that the government uses its authority to win its own interests and the interests of the owners of capital or with the benefit, but must be comprehensive and balanced.

\subsection{The role of the regional government in the cement plant in Rembang}

Since Tegaldowo villagers started their right of aspiration by asking about the existence of cement factories in their area, various positive and negative views emerged from various government parties or in a large structural system in both regency, provincial and national areas, and even some of them acknowledging the impact of the cement factory, but because they are tied to the system they do not dare to express, and prefer to be loyal to the system that forms it even though in their hearts they refuse, in other words the awareness of accepting risk lies in the characters in the community who adhere to consensus, and at any time being a dynamic group with the awareness tools they have become real awareness

Different attitudes and views of the government on the Semen Rembang conflict, give special meaning that, in general their awareness has begun to be built by history, how previous events created saturation points from the accumulation of events from noise, and greed of certain parties to tend to master with steps primordial business steps, which always use money tools to get everything (unilateral laisses faire), by being a landlord, king of the mountain, king of fish, king of mine, king of brokers and so on. This condition is called "the boundary" of modernization which has so far brought goodness and badness as well, has opened the heart of society in general to return to mechanical solidarity as described by Durkheim about the description of functional structural society in the framework of Ibn Kholdun's cycle. So, sooner 
or later the community will be formed in a unified system that is integrated with each other, based on functional awareness, and risk awareness, or called a system without limits.

Since the beginning of the attitude of the Regent of Rembang in the conflict of cement in Tegaldowo Village, Gunem Rembang Subdistrict, it tends to be subjective to the people who have different views on the Rembang cement plant, seemingly giving stereotypes of rural communities that are identical with ignorance and poverty. In other words, the Regent of Rembang still thinks of using the classical paradigm, which views that society must be obedient, submissive to the government, even though there is an unfair word in its micro context, which is different from the current society that has developed with its critical paradigm, and its reconstruction paradigm based on learn from experience that has been a source of daily learning. Although not in experiencing formal schooling, but with informality laden with experience, and with experience far more understood and understood, because in the substance of the experience there are scientific and natural facts, the level of success and truth is undoubted. In other words, natural scientific facts are very small, possibly intersecting with the principles of life and their beliefs that are based on real truth.

The attitude and views of the Rembang Regent towards the cement factory, saying that there was no conflict in Rembang, provided an understanding that the Regent was not sensitive to the problems that occurred in the lower society, which had been known enough, how the movement of the people of Tegaldowo and the surrounding area involved many supporting actors, who really wanted to open a dark veil that had happened between the community and mining companies before the cement plant, about environmental impacts, about land acquisition conflicts, and about the behavior of immigrants who had provided enough reason to reject a cement factory.

"From the beginning until now in Rembang there was nothing, which was a matter of people from outside Rembang. Like a motorcycle, the cement factory already has a SIM. If you already have a SIM how come you can't ride a motorcycle, that's wrong. Licensing that has been obtained is like a letter of permission to carry out activities ". (Suara Muria, 19 November 2014).

The attitude and views of the Rembang Regent also provided a bad precedent for the democratic education of the community by denying the truth about the conflict in Rembang, the truth about the social movements in fighting cement factories that had spread into the national sphere as if they were being influenced by the subjective interests of certain groups. minority under the pretext of truth belonging to the macro group. Education based on universal value values has shifted into a tool to reach values of importance, praxis value by using an old pattern that tends to be discriminatory which really intersects with modern pattern patterns that are owned by people today, who have learned a lot from various sources called experience which further strengthens and deepens their knowledge on the basis of essential truth.

Since the young men of mobilization did a dialogue movement with the Rembang Regent (formerly the Acting Regent) for the first time on September 13, 2013, in uncovering the problems that occurred in Tegaldowo Village people actually cornered the people rejecting the cement factory by saying that the land around the Watuputih mountain range was called land barren, dry, and it is very different from the thinking of the people who every day, get along with their land, enjoy the results of their land to date. A statement that contradicts the truth stated by the Regent of Rembang which gives confidence to the community that the partiality of the cement factory carried out by the Rembang Regent overrides the quality that needs attention, and the support from the leader. 
"Regency Government does not see the pros and cons of cement factories, but looks at the rights and obligations of the government. Because the factory has a permit, of course the regency government must carry out service obligations. But we also respect the rights of citizens who refuse. " (Suara Muria, 30 November 2014).

The statement delivered by the Regent of Rembang about not seeing the pros and cons of cement factories, creating prejudices which led to the question of what was happening with the Rembang Regency Government, was there an invisible hand as intended for something personal or group interest? It is clear from the statement that there is an inability of the District Government to provide public education about the truth, honesty as an important condition in the effort to smooth development. The open and bright attitude made by the Rembang Regency Government in an effort to support the cement factory in Rembang reflects that the District Government has only seen from the side of economic development, under the pretext of a cement factory increasing the Rembang Regency PAD, but not on the other side, how to create balanced economic development, economic improvement is not seen from the amount of income generated by mining companies, but can also be taken from other sectors, tourism, agriculture, plantations, natural product management, and so on.

The district government does not care about how the natural damage that occurred in Rembang was the impact of the liberalization of mining land that had shifted ownership from a farmer to a capitalist owner, how Rembang was referred to as a region with a great natural crisis, from Rembang North to southern Rembang experiencing the ecological crisis. Rembang, which is rich in natural resources, is not supported by management because of very little education and low human resources. The attitude of local governments is more dominant in using their personal rights in making conclusions, which tend to be subjective based on individual personal interests rather than individuals as a regional leader in a region. According to Midgal [6], mentioning that the ability of a State to achieve changes in society requires the role of leaders to strive to make state planning, public policies and actions, including the ability to involve the community (to penetrate), regulates social relationships and good governance of natural resources.

Rembang government's approach in the case of a cement factory, still uses a classical approach in a level of political democracy, where the Rembang government acts as a rent seeker, which is dominant in needs and the economy alone, authoritarianism, and not socio-cultural environment [7].

\subsection{The central government's response to the cement plant in Rembang}

Since Kendeng became Geger from 2009, until now due to differences in views from community groups with stakeholders with support from local and provincial government actors, who will have usefulness in economic values and have a positive impact on improving the welfare of many people, about kabundang people who live and live in the Kendeng mountainous region, due to environmental factors and coexistence of agriculture which is the daily livelihood of the people and is considered as a defense from an agrarian country which is the main pillar of the country.

The different views with the regional and provincial governments apparently did not thrill the central government to further examine and explore the conflict of the cement factory in Rembang, Central Java. Since the cement factory Rembang was upset, the President formed a special team of the Strategic Environmental Special Study (KLHS) team, which aims to 
straighten out the various problems that have been debated so far. Some of the things intended about environmental conditions are related to the ANDAL (environmental impact analysis) made by the cement factory loaded with interests, so that in the manufacturing process it is considered not based on reality or facts, and is considered to deliberately eliminate social elements of society. The ANDAL document should be a privacy document in an institution, but precisely in the case of a cement factory the document becomes a public commodity.

The KLHS study determines the continuity of mining companies that will stand in the Kendeng and Rembang Mountains areas. The first KLHS study has been carried out, and has assumptions about the sustainability of the Watuputih mountain range as a karst area and not suitable for mining. The SEA study has an important role in determining the decisions that will be taken by the President in uncovering the sustainability of cement plants in Rembang, Central Java in particular and on the island of Java in general, because of the increasingly ecological conditions of Java which are increasingly risky. Based on the findings of the above research, it shows that the role of the government as a regulator and facilitator does not work well, instead the government uses its authority based on leadership subjectivity, [8][9],[10], [11], [12]

\section{Conclusion}

The government's legitimacy on the use of policies towards the construction of a cement plant in Rembang is a dilemma because there is a dichotomy of views, thus creating policy imbalances and making the construction of cement plants in Rembang hampered, because of the centralized reformation towards decentralization, where regional autonomy is its main product. The recommendation that must be done immediately is to immediately make a quorum decision between the governments. 


\section{References}

[1] A. Budiman, Negara dan Pembangunan. Jakarta, Yayasan Padi Kapas, 1991.

[2] A. Budiman, Teori Pembangunan Dunia Ketiga. Jakarta: Gramedia Pustaka Utama, 2000.

[3] S. Kriesteva, Kapitalisme, Negara dan Masyarakat. yogyakarta: Pustaka Pelajar, 2015.

[4] suyahmo, Demokrasi dan Hak Asasi Manusia. Yogyakarta: Magnum Press, 2014.

[5] S. A. S. Sidik Puryanto, Ahmad Hariyadi, "PEMAHAMAN (LEARNING TO KNOW) KONFLIK DAN MALFUNGSI AGEN SEBAGAI SUBSTANSI PENDIDIKAN KONFLIK DALAM KASUS KONFLIK PABRIK SEMEN DI REMBANG JAWA TENGAH," J. Penelit. Pendidik., vol. 10, no. 1, 2018.

[6] J. S. Midgal, Strong Societies and Weak StatesState-Society Relations and State Capabilities in the Third World. 1998.

[7] Silaen Victor, Gerakan Sosial Baru: Perlawanan Komunitas Lokal Pada Kasus Indranayon Di Toba Samosir. Jogjakarta: IRE Press., 2006.

[8] Abdul Rochman Zaki, "Dampak Sosial Ekonomi Pertambangan Minyak Dan Gas Banyu Urip Kabupaten Bojonegoro (Studi Pada Masyarakat Desa Gayam Kecamatan Gayam Kabupaten Bojonegoro),” J. Adm. Publik, vol. 1, no. 2, 2013.

[9] A. S. Fatwal Fahrunnisa, Rosdianti Razak, "Peran Pemerintah Dalam Menangani Konflik Pemutusan Hubungan Kerja Karyawan Pt Gunung Mas Di Kabupaten Pangkep," J. Adm. Publik, vol. 3, no. 3, 2017.

[10] Vlado Vivoda, "Assessment of the Governance Performance of the Regulatory Regime Governing Foreign Mining Investment in the Philippines," J. Miner. Energy - Raw Mater. Rep., vol. 3, no. 3, 2008.

[11] Airong Zhang \& Kieren Moffat, "A balancing act: The role of benefits, impacts and confidence in governance in predicting acceptance of mining in Australia," Resour. Policy, vol. 44, pp. 25-34, 2015.

[12] and G. Lynda Cheshire, and Jo-AnneEveringham, "Governing the impacts of mining and the impacts of mining governance: Challenges for rural and regional local governments in Australia," J. Rural Stud., vol. 36, pp. 330-339, 2014. 